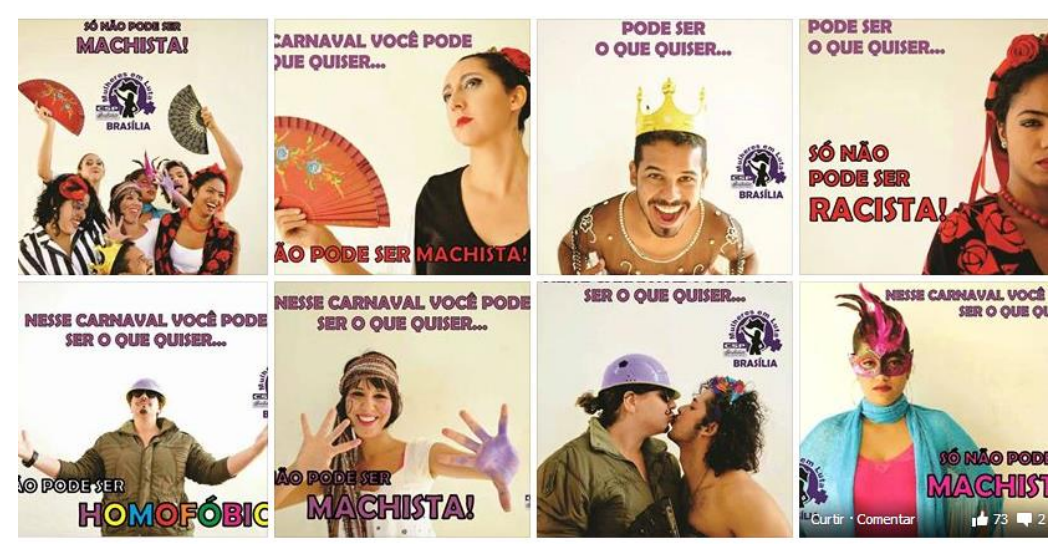

\title{
"No carnaval a fantasia é minha. O corpo é meu": memória e rupturas feministas na folia ${ }^{1}$
}

"At Carnival the costume is mine. The body is mine": memory and feminist ruptures in revelry ${ }^{2}$

\section{Dantielli Assumpção Garcia ${ }^{3}$ Lucília Maria Abrahão e Sousa ${ }^{4}$}

\begin{abstract}
Resumo: Neste artigo, da perspectiva teórica da Análise de Discurso pecheuxtiana, analisaremos alguns posts produzidos e/ou divulgados pelas Marchas das Vadias sobre o carnaval em suas páginas do Facebook. Mobilizaremos como noção teórica o acontecimento discursivo, com o intuito de explicitar como, na Marcha das Vadias, há a atualização de uma memória sobre a mulher e sua relação com o carnaval, com o homem e com a sociedade.
\end{abstract}

Palavras-chave: carnaval; mulher, Marcha das Vadias; acontecimento discursivo.

Abstract: In this paper, from the theoretical perspective of Pêcheux's Discourse Analysis, we study some posts on Carnival produced and/or released by Marcha das Vadias (The SlutWalk) on its Facebook pages. In order to carry out such an analysis, we make use of the theoretical notion of discursive event, aiming at elucidating how there is an update of a memory about the woman and her relation to Carnival, to man and to society as far as The Slut Walk is concerned. Keywords: Carnival, woman, The Slut Walk, discursive event.

\footnotetext{
${ }^{1}$ Este texto faz parte do projeto de Pós-Doutorado A Marcha das Vadias nas redes sociais: efeitos de feminismo e mulher, financiado pela FAPESP (proc. $\mathrm{n}^{\circ}$ 2013/16006-8), o qual tem como objetivo central analisar a formulação, a constituição e a circulação de um discurso sobre a mulher e o feminismo na contemporaneidade e no ciberespaço.

${ }^{2}$ This text is part of the Postdoctoral project entitled A Marcha das Vadiasnasredessociais: efeitos de feminismo e mulher (The SlutWalk on social networks: effects of feminism and womanhood) sponsored by FAPESP (process number 2013/16006-8). Whose main objective is to analyze the design, the establishment and the circulation of a saying about women and feminism in both contemporary times and cyberspace.

3 Pós-doutoranda na FFCLRP/USP. Mestre e Doutora em Estudos Linguísticos pela UNESP. Pesquisadora do E-L@DIS - Laboratório discursivo, sujeitos e sentidos em movimento (FAPESP). Bolsista FAPESP (proc. no 2013/16006-8). E-mail: dantielligarcia @ gmail.com. Endereço: Av. dos Bandeirantes, 3900 - Monte Alegre. CEP: 14040-901 - Ribeirão Preto, SP - Brasil.

${ }^{4}$ Livre-Docente em Ciências da Informação e da Documentação. Profa. do Curso de Graduação em Ciências da Informação e da Documentação e do Programa de Pós-Graduação em Psicologia, ambos da FFCLRP/USP. Coordenadora do E-L@DIS. Bolsista CNPQ. Bolsista FAPESP. E-mail: luciliamsr@uol.com.br. Endereço: Avenida dos Bandeirantes, 3900 - Monte Alegre. CEP: 14040-901 Ribeirão Preto, SP - Brasil.
} 


\section{1. "Mas é carnaval, vadia": que dizeres são estes?}

A festa carnavalesca é vista, pelo imaginário popular, como um espaço em que tudo é permitido, em que não há coerções, não há limites. Na folia, é permitido tanto vestir-se de outra pessoa para brincar o carnaval, como "agarrar", "beijar à força", "dedar", "puxar o cabelo", "passar a mão no corpo", isto é, violentar o outro. Nesse imaginário de permissividade, o sujeito que diz não a essa "liberdade opressora" é vítima, simbolicamente ou não, de uma violência. Diante desse cenário que violenta principalmente a mulher, surgem diversas manifestações contra essa legitimação "carnavalesca" da violência. Algumas dessas manifestações são produzidas pela Marcha das Vadias $^{5}$ e outros coletivos feministas e divulgadas nas páginas do Facebook. São esses posts que comporão nosso material de análise. Para esse artigo, escolhemos analisar: (1) uma campanha sobre o carnaval da Marcha das Vadias de Recife; (2) o texto "Mas é carnaval, vadia" - ou quando os homens chegam ao fundo do poço", de Leonardo Sakamoto, divulgado na página da Marcha das Vadias de São Paulo; (3) uma campanha da Revista Vip "Não seja um escroto neste carnaval", divulgada na página da Marcha das Vadias do Rio de Janeiro; (4) o post "No carnaval a fantasia é minha. O corpo é meu”, da página feminista do Facebook Acontece Comigo; (5) o post "Nesse carnaval você pode ser o que quiser...", do coletivo Mulheres em Luta; (6) uma mensagem, divulgada na Marcha das Vadias de Belo Horizonte, sobre Marchinhas na cidade de Contagem. Na análise desse material, pretendemos mostrar como um discurso-outro é trazido nas formulações como uma memória sobre a mulher e o carnaval. Memória esta que a Marcha das Vadias e outros coletivos feministas buscam atualizar, romper, na tentativa de fundar um outro discurso sobre a mulher e seu corpo na sociedade da folia.

Nosso trabalho divide-se em três partes. Na primeira, refletiremos sobre o carnaval e seus sentidos à sociedade brasileira. Na segunda, faremos brevemente uma discussão acerca da noção de acontecimento discursivo. Na terceira parte, analisaremos os posts divulgados nas páginas das Marchas das Vadias, mostrando como uma

\footnotetext{
${ }^{5}$ A Marcha das Vadias surgiu a partir de um episódio ocorrido em janeiro de 2011, quando o policial canadense Michael Sanguinetti, em uma palestra na Universidade de Toronto, recomendou que "as mulheres evitassem se vestir como putas para não serem vítimas de estupro". Como reação a sua fala, em abril do mesmo ano, cerca de três mil canadenses saíram às ruas para protestar na primeira Slut Walk, a Marcha das Putas, ou na tradução adotada no Brasil, a Marcha das Vadias. As manifestações das Marchas das Vadias espalharam-se pelo mundo e já em 2011 ocorreram em diversas cidades brasileiras.
} 
memória e uma atualidade entram em funcionamento, buscando compreender os atravessamentos discursivos na produção de outros dizeres sobre a mulher e a sociedade patriarcal.

\section{O carnaval no Brasil: os conflitos desfilam na avenida}

Constituidor da identidade nacional, o carnaval é visto por muitos como uma festa popular em que todos os indivíduos passam a conviver harmoniosamente nos quatro dias de folia. Apagam-se imaginariamente as diferenças cruciais entre classes e foliões de modo a instalar o efeito de que a circulação dos sentidos de violência estaria contida, bem como adormecidos estariam o conflito entre classes e os abusos de poder. O período das marchinhas guardaria a interrupção dos efeitos mais duros de desigualdade sejam eles de que natureza fossem.

Nos primeiros anos da República, as elites nacionais procuraram criar a imagem do país associado ao carnaval: "Muitos literatos, no início do século, percebiam a festa como uma manifestação que tivesse nascido e crescido em simbiose com a nação, entendiam os festejos de momo como algo homogêneo" (CUNHA, 2001, p. 13). Fruto de um processo que tem seus primórdios ainda na segunda metade do século XIX, o carnaval brasileiro formou-se pelo encontro entre os carnavais europeus (Paris, Nice, Veneza) e o entrudo - criticado pelas elites. Entrudo era a brincadeira com água, farinha e máscaras que desde o tempo da colônia garantia a diversão dos foliões. Explicitam Albuquerque e Filho (2006, p. 226) que:

Na imprensa, principalmente a partir de 1880, teve lugar uma exaustiva campanha contra o Entrudo. Circulares, decretos administrativos e punições, como multas e prisões, passavam a tratar especificamente dos mecanismos para reprimi-lo. Todo esse aparato legal foi mobilizado para convencer os festeiros a abandonar aquela forma de diversão. Grupos das elites brancas sonhavam em substituílo pelo carnaval nos moldes do que se via em Paris, Veneza ou Nice. A intensificação da repressão policial às práticas típicas do Entrudo e o surgimento das sociedades carnavalescas pareceram a inauguração desse tempo civilizador e o discurso civilizador era a camuflagem da moda para o racismo que permeava as relações sociais no Brasil.

Soihet (1998), ao analisar o carnaval carioca da Belle Époque ao tempo de Vargas, trabalhando as manifestações culturais da população pobre do Rio de Janeiro (1890-1930) como forma de resistência à discriminação e à opressão sofrida no cotidiano, explicita que o samba se transformou em um dos símbolos nacionais, ao mesmo tempo em que as concessões entre as escolas de samba e a ideologia do Estado 
varguista transformaram as primeiras em atração turística. O carnaval brasileiro, visto como um ritual de inversão da ordem cotidiana, um fenômeno que promove a ruptura do continuum da vida social diária, seria "a marca da individualidade, estando junto daquelas instituições perpétuas que nos permitem sentir nossa própria continuidade enquanto grupo" (Da Matta, 1987, p. 8-9). Já para Ortiz (1980), o carnaval existe a partir de uma ordem capitalista, sendo o Estado e as autoridades públicas que determinam o tempo e o espaço da festa, bem como os limites considerados toleráveis para a desordem. Não apenas isso, acrescentamos que hoje a administração dos efeitos do carnaval passa também por formas de controle da circulação das palavras e imagens dessa festa na mídia. Há canais de televisão detentores de direitos de transmissão em dada região ou lugar, há revistas que fazem a cobertura de certos camarotes, há sites que atualizam os passos da folia minuto a minuto. Como mostra Silva (2010), ao analisar o carnaval e o samba na historiografia brasileira:

O carnaval tem o seu grande momento uma vez por ano. Aliás, um tempo muito bem delimitado: o Estado estipula o feriado, a igreja declara o início da Quaresma e, com isto tem-se uma "desordem legítima". Durante o reinado de Momo, grande parte da população se volta para vivenciar esse fenômeno, o "povo" se transforma, as ruas se tornam um grande palco, onde todos dançam, brincam, divertem-se, ou seja, por um período curto - quatro dias, oficialmente - os limites entre o lícito e o ilícito tornam-se mais tênues, tem-se uma sensação de liberdade, que permite, por exemplo, que as pessoas se vistam de uma maneira mais livre ou exótica. Para muitos é o tempo da libertinagem, da luxúria, onde os prazeres da "carne", do corpo tornam-se preeminentes (SILVA, 2010, s.p.).

A partir dessas condições de produção, pretendemos analisar diferentes materiais produzidos ou divulgados pela Marcha das Vadias acerca do carnaval. Mostraremos como essa festa é vista como um momento em que tudo é permitido, em que é possível relacionar-se livre ou obrigatoriamente com o outro. Na época da folia, apagam-se os casos de violência, a criminalidade, as opressões. Nos quatro dias, o imaginário que se constitui à sociedade é o da alegria, da diversão. Contudo, a violência silenciosa permeia essa festa. É esse discurso da violência, principalmente contra a mulher, que os dizeres das Marchas das Vadias vão fazer circular na sociedade. Nas materialidades, são explicitados os conflitos, as relações de poder, as formas de violência contra o feminino, mas também contra os negros, os homossexuais. São nos diferentes materiais simbólicos que vemos o funcionamento da sociedade patriarcal que legitima e silencia uma violência, principalmente, contra a mulher em prol de momentos de folia. 


\section{3. $O$ acontecimento discursivo e 0 carnaval: memórias e atualizações}

Michel Pêcheux (1990) em Discurso: estrutura ou acontecimento, ao analisar o enunciado "On a gagné", cantado nas ruas de Paris após a vitória do candidato à presidência François Mitterrand, o qual passa a circular com um sentido diferente daquele em que o enunciado existiria ligado à prática esportiva, propõe vermos o discurso como uma materialidade igualmente constituída por uma estrutura e por um acontecimento. Para Pêcheux (1990, p. 19), o acontecimento é o fato novo, as primeiras declarações em "seu contexto de atualidade e no espaço de memória que ele convoca e que já começa a reorganizar". Assim, para o autor (1990, p. 17), o acontecimento é o ponto de encontro de uma atualidade e uma memória; o que se estabelece pela inscrição de um dizer antes estabilizado em outro lugar que passa a funcionar e fazer sentido de outro modo, criando outra inscrição de memória. Nas formulações das Marchas das Vadias, inscreve-se o dizer estabilizado acerca do carnaval como uma festa livre em um outro lugar, fazendo funcionar sentidos de opressão e violência a essa festa popular. Com a atualização dessa memória, outros sentidos passam a circular na sociedade e a interpelar os sujeitos que brincam o carnaval.

Buscando diferenciar tema e acontecimento discursivo, Guilhaumou e Maldidier (1993, p. 165-166) ressaltam que a noção de tema supõe a distinção entre "o horizonte de expectativas" - o conjunto de possibilidades atestadas em uma situação histórica dada - e o acontecimento discursivo que realiza uma dessas possibilidades, inscrevendo o tema em uma posição referencial. $\mathrm{O}$ acontecimento discursivo não coincide nem com a notícia jornalística, nem com os registros de um fato, designado pelo poder, na história. Ele é apreendido na trama dos enunciados que se entrecruzam em um momento dado. Assim, o acontecimento discursivo, possibilitando o surgimento de novos espaços de significação para o sujeito, pressupõe a relação entre dizeres que, ao se entrecruzarem, tendem a promover rupturas, ainda que um novo dizer seja, por princípio, formulado a partir das possibilidades que esse dizer encerra.

Ao formularem um dizer sobre a mulher e o carnaval, as Marchas das Vadias buscam romper com enunciados estabilizados, os quais sustentam que nesse evento festivo a mulher está no espaço urbano para servir como objeto de prazer ao homem. As formulações, produzidas/divulgadas pelas Marchas das Vadias, possibilitam o surgimento de novos espaços de significação ao sujeito-mulher, espaços esses em que a mulher pode se dizer livre e possuidora de desejos, entre eles, o de brincar o carnaval. 
Como em Zoppi-Fontana (1997, p. 51), o acontecimento discursivo é trabalhado aqui como ponto de quebra dos rituais enunciativos, como uma interrupção, uma emergência nas relações de continuidades definidas por esses rituais. Assim, o acontecimento discursivo é entendido como:

a ruptura de uma prática discursiva pela transformação dos rituais enunciativos que a definem; a interrupção de um processo de reformulação parafrástica de sentidos pelas mudanças das condições de produção; enfim, a emergência de um enunciado ou de uma posição enunciativa novos que reconfiguram o discurso, e através deste participam do processo de produção do real histórico (ZOPPIFONTANA, 1997, p. 51).

Em consonância ao proposto neste trabalho em relação à compreensão do acontecimento discursivo como um ponto de ruptura nos processos de significação, Indursky (2008, p. 9) define esse acontecimento como uma deriva, uma movimentação, muito intensa, dos sentidos em decorrência da qual se dá o surgimento de um novo domínio do saber. Para a autora (2008, p. 9), essa movimentação dos sentidos, registraria "não só o surgimento de um novo domínio do saber, mas também uma nova forma-sujeito".

Vemos as postagens das Marchas das Vadias sobre o carnaval como um acontecimento discursivo, em que há a interrupção de um processo de reformulação parafrástica (em que se sustenta um dizer sobre o carnaval como uma festa livre, alegre, sem violência) e a emergência de enunciados, da posição-sujeito-mulher-feminista constituída pela movimentação dos sentidos, a partir de uma desidentificação com o dizer dominante que a interpela para constituí-la como sujeito -, em que se busca romper com a naturalização da violência contra a mulher. Na ruptura, o discurso-outro surge como memória, todavia, os movimentos feministas buscam atualizá-la e reorganizarem sua prática discursiva, fazendo falar outra posição de um outro lugar. Rompem-se, portanto, desse acontecimento discursivo, rituais enunciados machistas que sustentam um dizer sobre a mulher na sociedade patriarcal e emergem outros dizeres sobre o "segundo sexo" que atualizam sentidos acerca da posição da mulher e de sua relação com o outro - sociedade e homem. 


\section{4. “Eu não estou pedindo nada! Carnaval não é desculpa pra me assediar": dizeres em confronto}

Nesta parte de nosso trabalho, analisaremos alguns posts que circularam nas páginas do Facebook das Marchas das Vadias (Recife, Belo Horizonte, São Paulo, Brasília, Rio de Janeiro) sobre a relação mulher-carnaval-homem-sociedade. Nossa finalidade é mostrar que essas postagens surgem como um acontecimento discursivo, o qual busca romper com uma memória estabilizada sobre a mulher e atualizar sentidos ao sujeito-mulher, ao sujeito-homem e ao carnaval.

Nas formulações das Marchas das Vadias, podemos perceber como o discursooutro é trazido como memória para ser rompido/atualizado pelo movimento feminista. Para analisarmos o discurso-outro, partimos de uma reflexão de Authier-Revuz (1990, 1998) acerca da heterogeneidade discursiva. Para a autora, há dois tipos de heterogeneidades: a constitutiva e a mostrada (esta subdividida em marcada e nãomarcada). A primeira não se apresenta na organização linear do discurso, uma vez que sua alteridade não é revelada, permanecendo no interdiscurso. A segunda traz marcas da presença do outro na cadeia discursiva, manifestando a alteridade ao longo do discurso. A heterogeneidade mostrada pode ser marcada, isto é, da ordem da enunciação e, portanto, perceptível na materialidade linguística (discurso direto, palavras entre aspas) e não-marcada, da ordem do discurso, sem visibilidade (discurso indireto livre, ironia etc). Assim, a heterogeneidade constitutiva é a presença do outro no discurso de forma não-mostrada, pois pertence à ordem do inconsciente. A heterogeneidade constitutiva constrói o discurso sócio-historicamente, está no seu exterior, atravessando as enunciações dos sujeitos. Já a heterogeneidade mostrada ocorre quando um locutor específico produz linguisticamente formas detectáveis no nível da frase ou do discurso que inscrevem o outro de forma marcada ou não marcada.

Em nosso corpus, o discurso-outro, além de aparecer marcado em algumas formulações sobre a mulher e sua relação com o carnaval, atravessa como memória, fazendo funcionar um dizer estabilizado sobre a mulher, seu corpo e sua relação com a

sociedade que brinca o carnaval. É esse discurso-outro que o movimento feminista da Marcha das Vadias intenta romper, fundando um outro dizer sobre essas relações carnavalescas.

Temos, assim, na Marcha das Vadias de Recife, as seguintes formulações: 


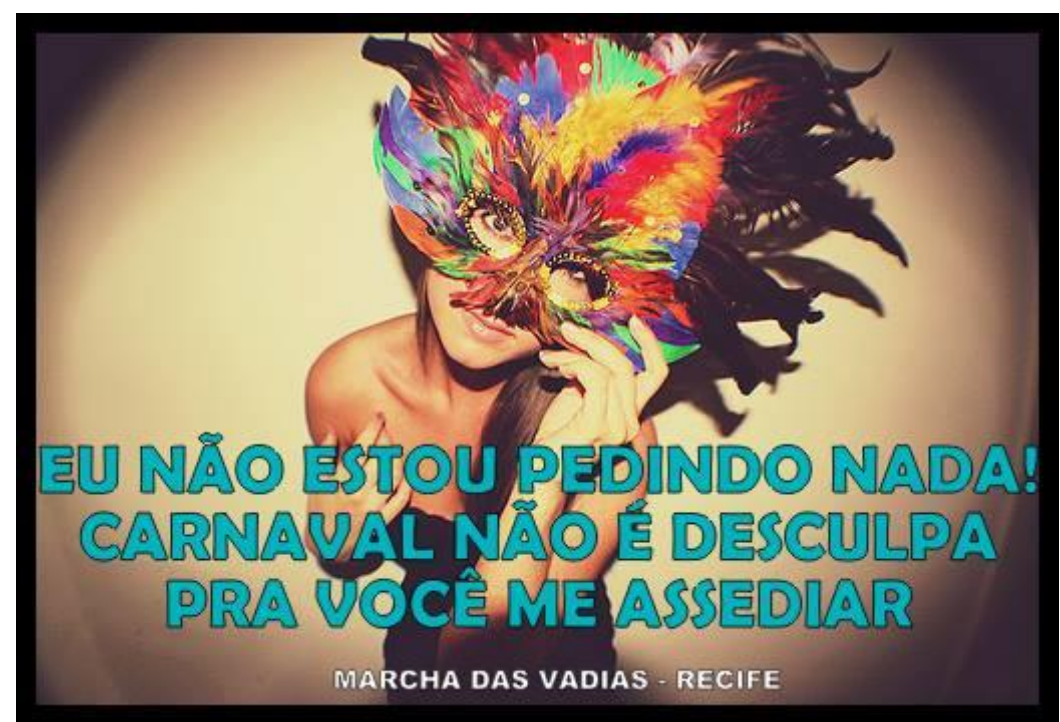

Figura 1: Marcha das Vadias de Recife

https://www.facebook.com/MarchaDasVadiasRecife?ref=ts\&fref=ts

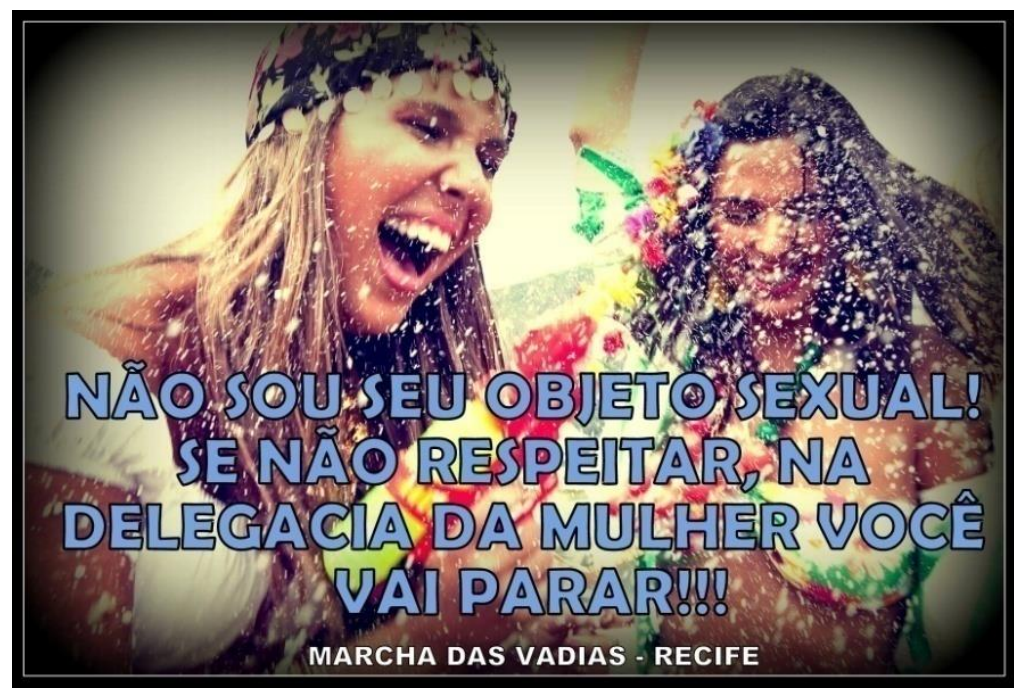

Figura 2: Marcha das Vadias de Recife

https://www.facebook.com/MarchaDasVadiasRecife?ref=ts\&fref=ts

A mulher, no discurso-outro, é aquela que está pedindo algo, é objeto sexual, é entretenimento para o homem, é corpo a ser assediado, ou seja, é aquela que durante a folia não tem condições de fazer valer a sua voz. Esses dizeres são trazidos como efeito de memória, visto que são dizeres que circulam em nossa sociedade e constituem sentidos ao/do feminino. A Marcha, por meio de um discurso da negação, atualiza essa memória, inscrevendo na língua que a mulher tem sim desejos, mas que nem a sociedade e nem o homem os controlam. Mais ainda, não se trata apenas de desejo, o que já seria muito diante do silenciamento da mulher em tantas cenas da vida privada, mas de direito ao desejo, ao corpo, ao prazer e à participação na folia. Busca-se explicitar que a mulher tem o poder sobre seu corpo, sobre seus desejos, seus atos, nestes termos, tem o desejo, o direito e o poder, o que a coloca em outra posição 
discursiva. É interessante observar como os corpos femininos estão apresentados com adereços de carnaval, mas sem a exposição da nudez e, por que não falar da mudez também; isso discursiviza um modo de dizer de si e de se colocar como mulher, qual seja, como aquela que brinca, se diverte e faz folia sem se deixar representar pela exibição do corpo nu. Isso marca uma ruptura com os sentidos naturalizados para o corpo da mulher, tão repetidos pela exposição midiática de pernas, glúteos e seios tal como promovido pelo discurso midiático.

Nos dizeres da Marcha, o homem que não respeitar isso "na delegacia da mulher vai parar". Na atualização de um dizer sobre a mulher, fica marcado que essa sabe de seu poder de denunciar atos violentos que venha a sofrer. A mulher da Marcha, que brinca carnaval, sabe que há instituições públicas - Delegacia da Mulher - que vai protegê-la, que vai ouvi-la, que vai punir homens violentos. A Marcha das Vadias de Recife busca atualizar sentidos para os atos violentos que as mulheres sofrem:

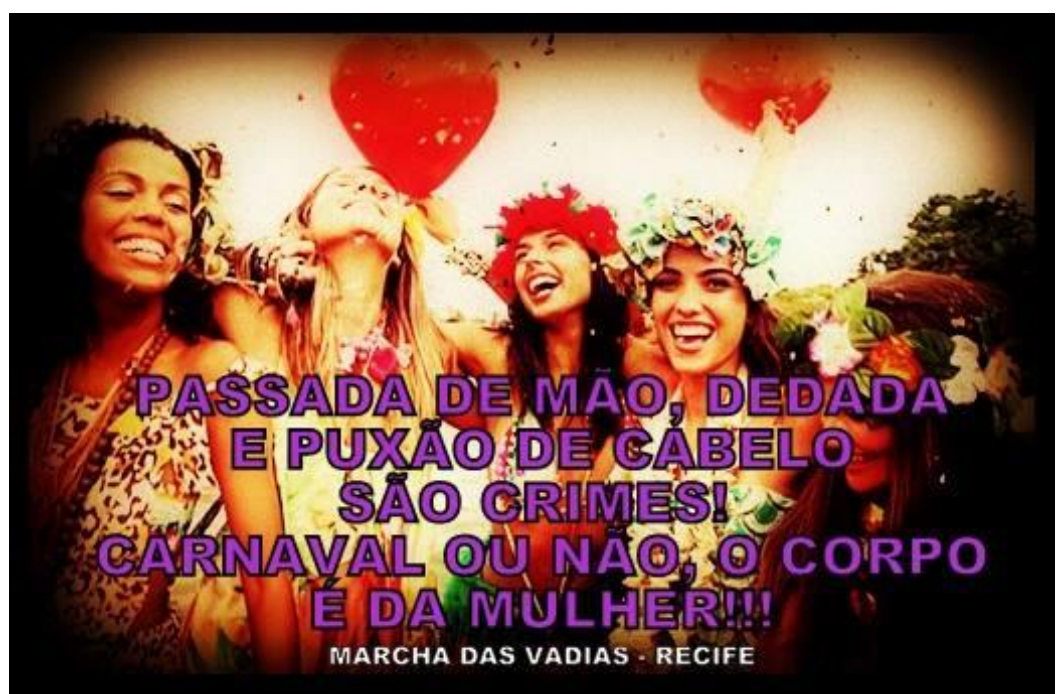

Figura 3: Marcha das Vadias de Recife

https://www.facebook.com/MarchaDasVadiasRecife?ref=ts\&fref=ts

Atitudes que a sociedade vê como naturais, principalmente em momentos festivos, como "passar a mão", "puxar o cabelo", "dedar", "beijar forçado", são colocadas pela Marcha das Vadias como crimes. A ruptura do ritual enunciado está nisso. O que a sociedade vê como "desculpa" é criminalizado pelo discurso da Marcha das Vadias. Além disso, o discurso da Marcha sustenta o empoderamento da mulher, seus desejos, o domínio sobre seu corpo, embora a sociedade silencie esses sentidos com atos de violência seja ou não no carnaval. Observamos ainda que o corpo passa a ser discursivizado como algo de que se é dono, ou seja, tal "propriedade" é particular e reclama a permissão da dona para ser manipulado ou tocado. Marcar as formas 
cotidianas de "fazer brincadeiras" com o corpo feminino como formas de violência é outro deslocamento importante que aqui gostaríamos de pontuar. O que antes era tido como coisa cotidiana ou brincadeirinha para o discurso estabelecido como natural, aqui passa a sofrer rachadura ancorado pelos significantes "crime" e "estupro". Isso estabelece o lugar da lei como parte da sustentação dos direitos da mulher, a lei e os direitos, a lei e as sanções para aqueles que atravessarem o sinal vermelho. Ao falar em crime, a mulher coloca-se amparada pelo poder de ter direitos, de reconhecê-los como seus e de conhecer os abusos como crimes, o que inscreve uma posição absolutamente outra em relação a atos antes traçados como brincadeiras aparentemente inofensivas.

A Marcha das Vadias de Recife também busca romper com certos dizeres sobre a mulher negra e com o imaginário sobre ela estabilizado pelo discurso midiático. Vejamos.

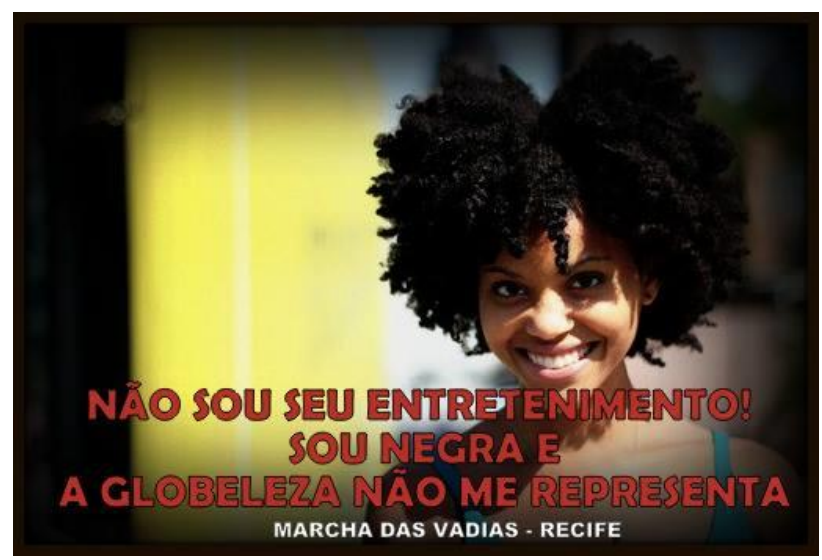

Figura 4: Marcha das Vadias de Recife

https://www.facebook.com/MarchaDasVadiasRecife?ref=ts\&fref=ts

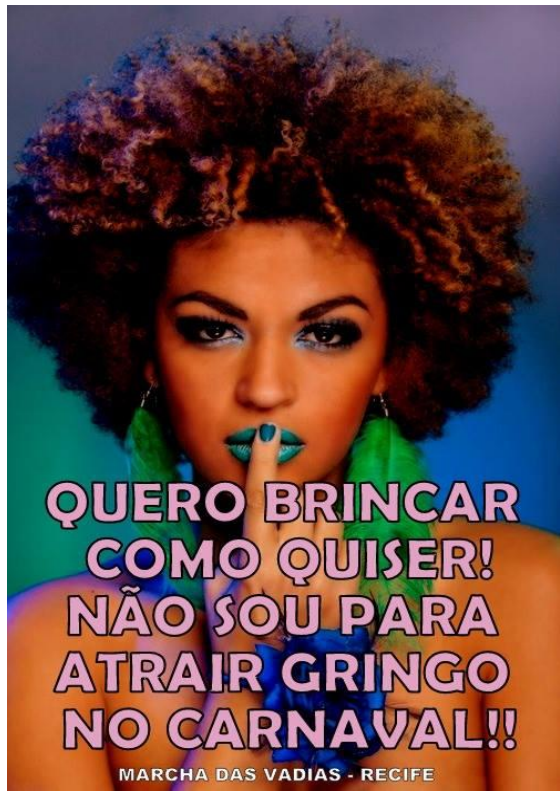

Figura 5: Marcha das Vadias de Recife

https://www.facebook.com/MarchaDasVadiasRecife?ref=ts\&fref=ts 
O discurso-outro sustenta que a mulher, principalmente a negra, tem como função na sociedade e no carnaval "atrair o homem estrangeiro", dada a forma como os sentidos de mulata foram desenhados desde a escravidão, aquela que serve ao senhor em todos as instâncias da vida privada inclusive. Tal sentido dominante foi inscrito sóciohistoricamente e cristalizou-se como único modo de dizer do corpo da mulher negra, peça ou objeto a ser comprado e usado na e fora da cama. Ressaltamos o modo como partes desse corpo feminino negro foram discursivizados na matriz escravocrata que sustentou e ainda sustenta efeitos: seios fartos das amas de leite, o que garantiria potência para a amamentação, além de nádegas avantajadas e lábios grossos, capaz de assegurarem satisfação sexual para os senhores. Tais efeitos, pelo modo como constituíram um dizer oficial e dominante, estabilizaram certa imagem sobre o corpo da mulher negra, imagem esta que os cartazes acima fazem furar/atualizar.

A mulher é colocada como um objeto de diversão, como um objeto a ser comercializado nas propagandas da Globo. A Globeleza não representa as mulheres porque deixa a sociedade usar seu corpo como símbolo do carnaval, do Brasil. A mulher negra surge como entretenimento ao estrangeiro, podendo ser "exportada" a outros países, que também a violentarão e legitimarão sua posição como objeto de desejo. Uma crítica a esse discurso é divulgada na Marcha das Vadias de Belo Horizonte.

Antes de passarmos à análise desse texto, é importante salientar que em nossas análises estamos mobilizando a noção de recorte (Orlandi, 1984). O gesto de recortar visa ao funcionamento discursivo, buscando compreender o estabelecimento das relações significativas entre os elementos significantes. Ao analisarmos os recortes unidades discursivas - dos textos, pretendemos refletir sobre as condições de produção atuais que permitem a emergência de dizeres que rompem com rituais enunciados e estabilizados na memória.

No dia 21 de fevereiro de 2014, a Marcha das Vadias de Belo Horizonte compartilha um texto sobre um concurso de marchinhas na cidade de Contagem (MG). Esse texto, em tom de manifesto, faz uma crítica ao edital lançado pela Fundação Municipal de Cultura de Contagem para a inscrição de marchinhas, o qual previa que o tema das canções era "livre", porém, era "proibida qualquer tipo de manifestação de desapreço a órgão ou entidade da Administração Pública Direta e Indireta, a grupo social, organizações, pessoas físicas e instituições privadas". O que causa estranhamento, inicialmente, é a censura ao conteúdo das marchinhas. Contudo, o que o 
texto busca trazer à tona são as marchinhas que foram contempladas pelo edital: "Mulata tipo exportação", de Edson Pereira, e "Loirinha do BBB", de Wilton Batata:

(1) Uma das marchinhas, chamada "Mulata tipo exportação", de Edson Pereira tem um conteúdo extremamente machista e racista, incitando o tráfico de mulheres, com letra que diz: "Japonês caiu no samba e no meio da batucada conheceu uma mulata da boca prateada, do bumbum arrebitado, um corpo de violão. Japonês ficou maluco com a mulata rebolando no salão. Boca loca mais que bocão eu vou levar essa mulata pro Japão. Essa mulata é do tipo exportação.”

(2) Outra das marchinhas, chamada "Loirinha do BBB", de Wilton Batata, tem a letra: "Eu fungo e ela funga, também gosto de beijar. Depois, eu fico de olho nela, no buraco da janela. Só pra ver ela lavar (lavar o quê?) lavar a roupa. Lavar o chão! Alô loirinha capricha no escovão. A loura é bonita, gostosa e cheirosa. Com o seu vestido transparente cor de rosa. O sonho dela era entrar no BBB. Cuidado menina assim você vai me perder."

O texto explicita uma memória estabilizada da posição que a mulher deve ocupar na sociedade. A mulher branca deve ficar em casa, sendo observada pelo homem. Já a mulher negra deve ser exportada para dar prazer ao estrangeiro - vemos aí um discurso do tráfico de mulheres, do tráfico sexual. $\mathrm{O}$ manifesto pede ajuda às páginas feministas para tentar romper com essa "cultura da violência" e com a legitimação do Estado da violência contra a mulher. Em tom de denúncia, o texto clama pela constituição de um outro dizer sobre a mulher: "É inadmissível que um órgão público, a partir de um edital e, principalmente, utilizando dinheiro do contribuinte, financie esse tipo de absurdo contra a dignidade das mulheres".

Nas páginas da Marcha das Vadias, são compartilhados textos que tentam produzir furos, rupturas nos discursos que circulam na sociedade sobre a mulher no carnaval; rompem com rituais estabilizados na sociedade quando se fala sobre a mulher e seu corpo na folia, amparada pelo direito, dotada de um poder outro. Um exemplo é o texto "Mas é carnaval, vadia - ou quando os homens chegam ao fundo do poço", de Leonardo Sakamoto, compartilhado na página da Marcha das Vadias de São Paulo.

Esse texto busca produzir uma reflexão acerca das atitudes masculinas no carnaval quando o assunto é "conquista". O texto confronta as posições da mulher e do homem na sociedade e, principalmente, na folia carnavalesca. Sakamoto traz como uma memória certas relações entre homens e mulheres. É essa memória que se questiona:

(3) Adoro carnaval de rua. E São Paulo está ótima com os blocos que polvilham a cidade. É claro que, em meio a essa fauna exuberante, há sempre alguns com a velha tática de "conquista" da idade da pedra lascada, que consiste em "abater a presa e consumi-la ainda viva". 
(4) Juro que não sei onde enfiar a cara de vergonha quando um rapaz agarra o braço de uma moça e insiste que só o largará quando receber um beijinho. Ou quando o piolho dá um "armlove" e, insano, tenta arrastar a moça até ser contido por outros foliões - ou não. Presenciei uma cena patética e recorrente: depois de receber uma miríade de respostas desabonadoras, e sem soltar o braço de uma mulher bastante educada, um deles pediu "por favor, por favor, me dá um beijo". Cara, cadê sua dignidade? Isso é o fundo do poço! O amor próprio é o primeiro a morrer quando a alcateia está olhando.

Sakamoto aproxima o comportamento masculino ao comportamento de animais. As mulheres surgem como presas que serão abatidas pelo homem. Na sociedade machista, a mulher nada mais é que um objeto a ser consumido, devorado, principalmente, quando a "alcateia" está olhando e analisando o funcionamento do poder masculino sobre a "presa-mulher".

Ao mostrar uma naturalização da violência, ao mostrar que isso é reflexo de uma educação machista, Sakamoto tenta romper esses dizeres e atualizá-los com outros sentidos ao "segundo sexo", materializando o empoderamento da mulher. Embora esteja vivendo no espaço público, à mulher não lhe é permitido estar sozinha, não lhe é permitido dizer não, não lhe é permitido divertir-se nem no carnaval. Mesmo denunciando o homem pela violência sofrida, a mulher é violentada por meio das designações dadas a ela. A sociedade, pelo funcionamento da ideologia, faz com que a mulher veja como natural a violência que sofre, afinal, ela "procurou” por estar sozinha, por se divertir, por dizer não:

(5) Mas, em comparação a outros carnavais, tenho a grata impressão de que há mais pessoas conscientes e sentindo-se empoderadas para não deixar barato esse tipo de assédio sexual. Fiquei sabendo de casos em que a polícia foi acionada e pôs água no chope dos desmiolados que achavam que a bunda alheia é patrimônio público.

(6) Em outro momento, depois de dar um tapa na cara de um sujeito que tentara the beijar à força, uma colega ouviu alto e bom som, quase como uma crítica social: "Mas é carnaval, vadia! Quem está aqui sozinha é porque quer isso". O sujeito aprendeu com amigos e família, viu na televisão, ouviu no rádio, que este é um momento em que as regras de convivência estão suspensas e todos procuram sexo. Para ele, a rua é um imenso Tinder offline (não que todos usem o app dessa forma, mas o desespero de alguns por lá é deprimente). Daí, quando rejeitados, expressam toda a sua perplexidade em bordões como "vagabundas", "vadias" e "piranhas".

Duas posições à mulher são trazidas ao texto. Uma, legitimada pela sociedade, a "mulher de bem"; e a outra, vítima de violência que esta mesmo provoca, " $a$ vagabunda", "a piranha", "a vadia", "a mulher da vida”. A “mulher de bem” está em casa à espera de seu homem, a vadia está na rua, está brincando o carnaval. A sociedade machista, aparentemente, não aceita a mulher no espaço público, esta, nesse lugar, é 
vista como uma "mulher da rua", "sem valor". A mulher valorizada é aquela submissa à sociedade e ao homem, é a que será sua "psicóloga", "enfermeira", "cozinheira", "objeto sexual", isto é, será uma propriedade masculina. A mulher que é livre é vítima da violência sustentada pelos discursos da sociedade. O que Sakamoto apresenta em seu texto é que a sociedade produz e sustenta uma violência contra a mulher e essa violência fará parte da memória a qual os movimentos feministas tentam romper, furar. As Marchas marcam que a violência contra a mulher não pode ser uma "tradição", não pode continuar a produzir efeitos que subjugam o feminino e legitimam o masculino. Os "corretivos sociais" não podem continuar a ocorrer para manter a mulher presa ao espaço privado, sem a possibilidade de viver uma vida livre. As que escolhem essa vida livre podem ser violentadas, afinal, elas estavam "à disposição":

(7) para esses jovens, provavelmente não se enquadram na categoria de "vagabundas" apenas suas mães e avós, que dormem o sono das santas católicas, enquanto quem é "da vida" povoa o carnaval. Porque "mulher de bem" está em casa a essa hora, não aceitaria nunca colocar um vestido acima do joelho e deixar as costas de fora, não bebe, fuma ou tem vícios detestáveis, não ama apenas por uma noite e não ri em público, escancarando os dentes a quem quer que seja. "Mulher de bem" permanece em casa para servir o "homem de bem" e estar à sua disposição como empregada, psicóloga, enfermeira, cozinheira ou objeto sexual, a qualquer hora do dia e da noite.

Por quê? Porque, na sua cabeça, elas pertencem a eles. Porque assim sempre foi, é assim que se ensinou e foi aprendido. É a tradição, oras! E o discurso da tradição, muitas vezes construído de cima para baixo para manter alguém subjugado a outro não pode ser questionado. Quem ousa sair desse padrão, pode ser vítima de alguns "corretivos sociais".

Ao mostrar o discurso-outro, Sakamoto atualiza essa memória, apontando que o "homem chegou ao fundo do poço" ao precisar violentar a mulher, seja física ou psicologicamente, para legitimar sua posição na sociedade. A falta de "amor próprio" faz com que o homem use de um discurso da violência para subjugar a mulher e dizer que esta não tem outra posição na sociedade a não ser a de objeto de prazer e submissão do/ao homem. Como forma de confrontar esse poder masculino sobre a mulher, a revista VIP divulga, em sua página do Facebook, a matéria "No carnaval, assédio não pode ser fantasia". Essa matéria será compartilhada na página do Facebook da Marcha das Vadias do Rio de Janeiro.

No comentário da Marcha das Vadias acerca desse artigo - "Muito bom. Já que o povo que lê a VIP não acompanha a gente uma mensagem direta pro Carnaval" -, ficam marcadas certas relações entre homens e mulheres. Por ser uma página feminista do movimento Marcha das Vadias, o site não será lido, como colocam, por homens que 
leem a revista VIP. Para a Marcha, os homens que leem essa revista, em geral, são machistas ou não apoiam as causas feministas. A VIP é uma revista direcionada ao público masculino e contará com artigos sobre futebol, dinheiro, diversão e mulher. Essa publicação, com um gesto de ruptura, busca produzir outros dizeres sobre a mulher, o homem e o carnaval. Com o slogan "Não seja um escroto neste carnaval", vai formulando e atualizando dizeres que questionam certas atitudes masculinas, vistas como naturais, diante do sexo oposto. A matéria foi escrita pela jornalista Juliana Faria, a qual criou a campanha "Chega de Fiu Fiu" e o site "Think Olga". Um gesto de ruptura da revista VIP está em convidar uma feminista para escrever em uma revista direcionada ao público masculino que vê, muitas vezes, a mulher como objeto. A publicação tentará romper com esse imaginário que circula em nossa sociedade.

A matéria da revista é constituída por meio de um discurso da interdição, dizendo ao homem o que ele pode e o que não pode fazer no carnaval e com a mulher. Além disso, traz também à formulação um discurso estatístico que busca mostrar por meio dos números os vários casos de violência contra a mulher. A revista VIP coloca-se contra essa violência, ressaltando ao homem que este pode ter fantasias, mas não a do assédio, da violência, isto é, o homem pode fantasiar-se do que quiser, menos de homem violento, que sente prazer em assediar a mulher. Se ele decidir assediar, estará sendo um "escroto", um homem sem valor. A campanha é para o carnaval, todavia, a revista espera que, após essa festividade, os homens continuem respeitando as mulheres, pois estas agradecem. Ao dizer que as mulheres agradecem o fato do homem respeitálas, parece que os homens fazem um favor ao sexo oposto e não mudam realmente suas atitudes. $\mathrm{Na}$ fantasia, os homens mudam, porém, na realidade, ainda teriam comportamentos violentos:

(8) No carnaval, assédio não pode ser fantasia Mais de $80 \%$ das mulheres não gostam de receber as tais cantadas na rua. Cerca de $90 \%$ delas já deixaram de fazer alguma coisa por medo de assédio. $85 \%$ já sofreram com estranhos passando a mão em seus corpos. O site da VIP convidou a jornalista responsável pela campanha Chega de Fiu Fiu para reforçar nosso coro: não seja um escroto neste carnaval. E nem depois. As mulheres agradecem

Nesse texto, a imagem da mulher é a da vítima violentada, mas que, socialmente, aparece como figurante na encenação do carnaval. O homem é o galanteador, o que conta vantagem por ter assediado a mulher. O homem vê o assédio como algo "normal" - pois os filmes, a publicidade, os amigos sustentam esse sentido - e o que texto atualiza é a não naturalização da violência contra a mulher: 
(8) "No carnaval, pode tudo" é uma frase que deveria dar arrepios em qualquer um. A festa, por vezes, mascara a violência sexual que muitas mulheres sofrem durante a celebração do feriado.

(9) Puxões, encoxadas, beijos forçados, mão boba, um tapinha que "não dói”... Quem nunca ouviu falar dessas histórias? E ela é sempre contada do ponto de vista do homem "galanteador", seja em filmes, anúncios publicitários ou mesmo na boca de um amigo. A graça da conquista é a protagonista, merecedora de aplausos, risadas, high fives. O consentimento, por outro lado, não tem espaço neste roteiro.

(11) Se você cortar a cena e jogar luz para quem foi esquecida como figurante, vai enxergar coisas que talvez não gostaria: medo, aborrecimento, vergonha e traumas.

Por meio de narrativas de experiências, enviadas ao "Chega de Fiu Fiu" campanha contra o assédio em lugares públicos -, são trazidos exemplos de violência sofrida pelas mulheres:

(12) "Ao ignorar um grupo de homens que me cantavam, levei um tapa na bunda. Eles riram. Eu chorei de dor e humilhação."

(13) "um homem de moto diminuiu a velocidade ao passar por mim e enfiou a mão no meio das minhas pernas"

(14) "de repente, um cara se aproximou de mim com o pau pra fora."

(15) "um motoqueiro gritou "sobe aqui e eu te mostro como se trepa."

Esse texto, posto em circulação na VIP, sustenta que o assédio é algo "grave $e$ não tem limites". Essa naturalização é legitimada pela sociedade, pelas propagandas, pelos formadores de opinião, porém, ao atualizar essa memória, a VIP tenta romper essa discursividade, mostrando que o homem que age assim é um "escroto", que não respeita a mulher:

(16) O assédio é grave e não tem limites, nem mesmo de idade: algumas mulheres me confidenciam que sofreram pela primeira vez com o problema aos dez, nove e até oito anos. Infelizmente, tal comportamento é visto com normalidade por grande parte das pessoas. Também é legitimado por propagandas e formadores de opinião (!) equivocados, que confundem as relações românticas naturais humanas com a violência e agressividade do assédio sexual. No carnaval, caia na farra, mas não caia nessa. E respeite as mulheres.

O homem que lê a VIP pode cair na farra, pode divertir-se no carnaval, todavia, não pode violentar as mulheres. Mais uma vez o discurso da interdição produzindo efeitos. A ruptura nos posts está em elaborar discursos que não interditam a mulher, mas sim o homem. Nesses posts sobre o carnaval, não é a mulher que não pode fazer certas 
coisas, que não pode agir como queria e sim o homem. $\mathrm{O}$ homem que não pode ser machista, que não pode ser "escroto", que não pode ser violento.

A Marcha das Vadias de São Paulo compartilhará em sua página do Facebook uma campanha do coletivo "Acontece Comigo" que também tentará romper com certos sentidos estabilizados sobre a relação mulher-carnaval-homem-sociedade. Indo à página "Acontece Comigo" vemos um convite direcionado às mulheres para participarem da campanha "Pelo fim da violência e assédio sexual no carnaval". Temos assim um convite à militância pelo espaço digital. A cibermilitância se dará pelo envio de textos para a campanha e pelos compartilhamentos em outras páginas do Facebook.

O pedido do movimento é para que as mulheres enviem relatos se já vivenciaram ou presenciaram algum tipo de violência no carnaval. Essa campanha passará a circular nas páginas do Facebook. Todos os relatos mostram situações de violência contra a mulher no espetáculo do carnaval. O discurso formulado pelo coletivo busca romper com um discurso que naturaliza a violência contra as mulheres no carnaval, o qual reproduz que o corpo da mulher é de todos nessa festa. A formulação tenta romper com essa memória, atualizando-a com a formulação: “No carnaval, a fantasia é minha. $O$ corpo é meu". Mostra-se, dessa forma, que a mulher detém o poder sobre seu corpo e não a sociedade, o homem como esperam que a mulher acredite.

Na campanha, há o confronto entre um imaginário e um real, de acordo com o movimento feminista, acerca do carnaval. A memória da folia nos remete ao momento da "liberdade sexual" em que todos podem "vestir fantasias e espalhar pelo espaço público". Contudo, esse "todos" não inclui a mulher, uma vez que "os homens entendem como liberdade sexual a possibilidade de exercer seu desejo independente da vontade alheia. Aproveitam da multidão e do suposto clima de liberdade para assediar e abusar de mulheres que tentam se divertir". No espaço público, não é dado à mulher o direito de divertir-se, esta fica até "amedrontada" de permanecer e conviver no espaço urbano. A essa, no espaço da cidade, só resta uma violência legitimada pela sociedade, que vê na mulher livre (esteja ela "bêbada, chapada" ou não) o direito de abusá-la: "Entendem os corpos femininos, principalmente de mulheres bêbadas ou chapadas, como disponíveis e prontos para suprir suas vontades". A ruptura, produzida pelo coletivo e que circulará em outras páginas feministas, está em mostrar um deslizamento de sentido sobre o carnaval. Na memória, o carnaval é libertador, tudo é permitido na folia; na atualização dessa memória pelo movimento feminista, o carnaval é opressor, aprisiona a mulher e seus desejos, uma vez que é sustentado por uma sociedade machista. Assim, 
de espetáculo de liberdade, o carnaval passa para espetáculo de opressão: "Como resultado dessa cultura machista e opressora, o carnaval para as mulheres acaba sendo, muitas vezes, justamente o contrário de liberdade. Vítima de diversas violações e atrocidades, se sentem acuadas. O cenário carnavalesco se transforma em espetáculo de opressão".

Nessa campanha, o movimento feminista tenta fundar uma outra discursividade, explicitando que a mulher tem poder sobre seu corpo, que esta pode usar suas fantasias e ser livre. Ao relatar certas situações vivenciadas pelas mulheres, busca-se, mais uma vez, romper com a naturalização da violência. $\mathrm{O}$ homem vê como tão comum essa violência contra a mulher que até a revista VIP, como salientamos, tenta romper com essa memória, ressaltando que o homem que age de forma violenta, sem o consentimento da mulher é um "escroto". Nas campanhas sobre o carnaval elaboradas pelos movimentos feministas, o acontecimento está em inscrever o discurso em outras regionalizações de sentidos, regiões estas que atribuem um lugar à mulher na sociedade. Em reformulações parafrásticas sobre a naturalização da violência contra a mulher, as páginas fazem circulam outros sentidos sobre a mulher. A mulher, nos dizeres dos movimentos, é livre, tem poder sobre si, não tem medo de denunciar o homem.

Outro compartilhamento sobre a mulher e o carnaval estará na página da Marcha das Vadias de Brasília. As Marchas das Vadias, ao divulgarem/compartilharem certos links, marcam as relações entre os movimentos feministas, fazem circular, pela reformulação dos discursos, outros sentidos à relação mulher-carnaval-homemsociedade. A campanha que circulará na página da Marcha das Vadias de Brasília foi produzida pelo coletivo "Movimento Mulheres em Luta DF": 


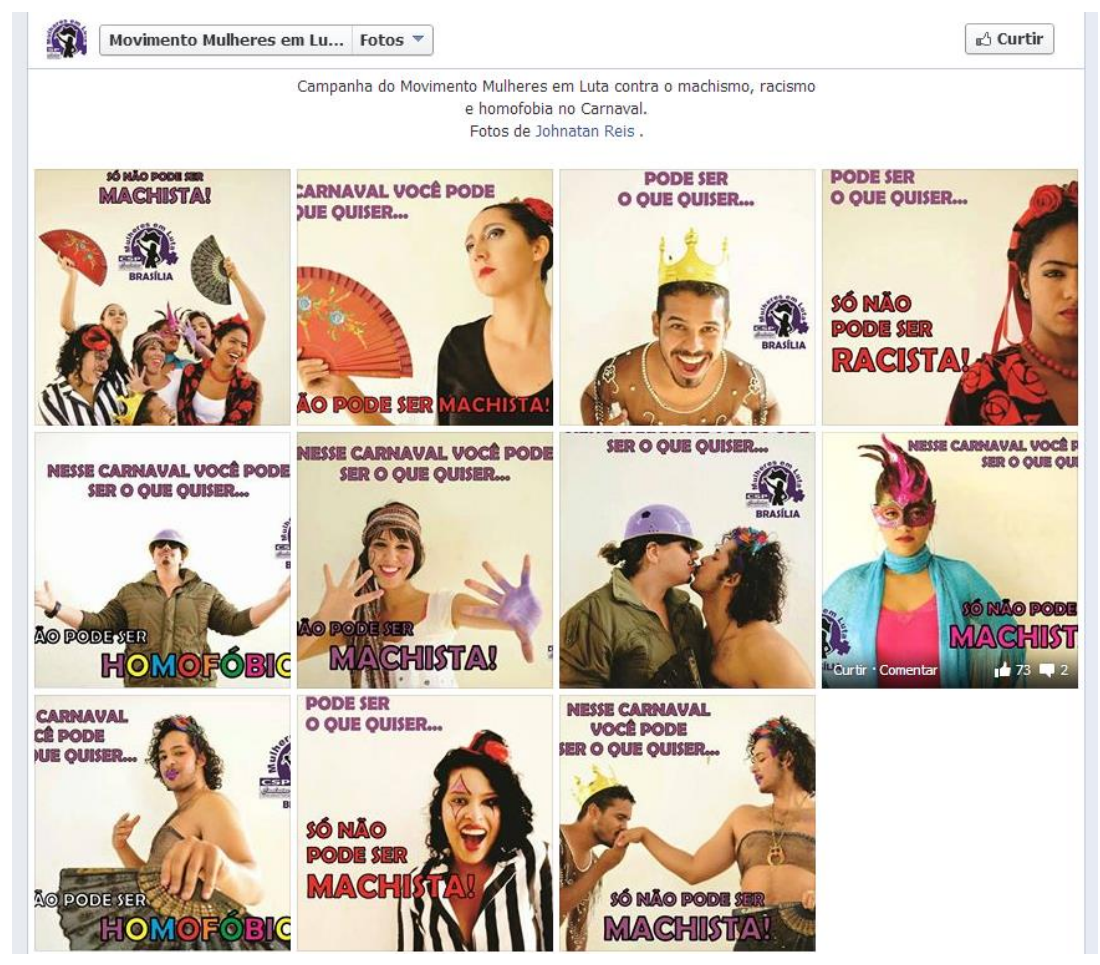

Figura 6: Movimento Mulheres em luta

https://www.facebook.com/media/set/?set=a.217817528408105.1073741829.217220611801130\&type $=1$

O discurso dessa campanha busca romper com um funcionamento da sociedade atual em que o discurso machista, homofóbico, racista se faz fortemente presente. Ao usar "você", podemos dizer que a campanha é direcionada a um sujeito qualquer (homem, mulher, homossexual). Não se especifica quem é esse sujeito, há uma indefinição. Esse sujeito, como colocado, é livre para ser quem quiser, isto é, enquanto fantasia, ele pode se vestir de qualquer coisa. Todavia, enquanto sujeito que vive em sociedade não pode ser machista, homofóbico e racista, ou seja, não pode se filiar a sentidos estabilizados de violência. O discurso da campanha constitui-se por meio da negação, buscando interditar certos rituais, certos comportamentos. Teríamos:

\section{Você pode X, só não pode Y}

O y aponta para uma memória que funciona em nossa sociedade, a qual o movimento feminista busca romper, atualizar. $\mathrm{O} x$ abre para uma polissemia, para uma multiplicidade de sentidos a serem preenchidos pelo sujeito. $O$ sujeito pode ser dançarino de flamenco, rei, espanhol, hippie, colombina etc. Salienta-se, assim, uma liberdade permitida pelo carnaval quando o assunto é fantasia, e aqui vale a polissemia do termo fantasia. O carnaval, como explicita a campanha, só não deve permitir a violência, seja ela contra a mulher, contra o negro ou contra o homossexual, ou seja, se 
a violência tem uma inscrição sócio-histórica bastante forte e acentuada e se os sentidos de violência são regularizados e legitimados em "pequenos atos", em "brincadeiras", em coisas tidas como normais, os discursos que estamos analisando dão um basta, estabelecem um corte, rompem com a manutenção do mesmo, fazem acontecimento.

Portanto, neste artigo, buscamos mostrar como os movimentos feministas atualizam sentidos acerca da relação mulher-carnaval-homem-sociedade. Ao retomar certas memórias sobre essa festa popular, os discursos feministas explicitam como a sociedade violenta a mulher ao dizer que na folia tudo é permitido. As campanhas apontam para uma posição-sujeito-mulher que a sociedade tenta silenciar: a mulherlivre, que quer se divertir, que tem poder sobre seu corpo, que não quer ser objeto sexual, que não quer atrair gringo para o carnaval. Ao negar/interditar certos sentidos atribuídos à mulher, os movimentos feministas afirmam/legitimam uma posição ao "segundo sexo", fundam um acontecimento discursivo em que se interdita o homem, evidenciando a este o que ele pode ou não fazer em sociedade. $\mathrm{Na}$ atualização de um dizer, não é a mulher que não pode agir no espaço público, mas sim o homem. Rompese, assim, a memória de que o homem pode tudo e à mulher só lhe resta submeter-se à sociedade patriarcal. Nos posts sobre o carnaval, a mulher é empoderada e o homem é visto como violento por não respeitar a mulher e não ter amor próprio.

\section{Referências Bibliográficas}

ALBUQUERQUE, Wlamyra R. de; FILHO, Walter Fraga. 2006. Uma história do negro no Brasil. Salvador: Cento de Estudos Afro-Orientais; Brasília: Fundação Cultural Palmares.

CUNHA, Maria Clementina Pereira. 2001. Ecos da folia - uma história social do carnaval carioca entre 1880 e 1920. São Paulo: Cia das Letras.

GUILHAUMOU, Jacques; MALDIDIER, Denise. Efeitos do arquivo. A análise do discurso ao lado da História. 1993. In: ORLANDI, Eni Pulcinelli (Org.). Gestos de leitura: da história no discurso. Campinas: Editora da Unicamp.

INDURSKY, Freda. 2008. Unicidade, desdobramento, fragmentação: a trajetória da noção de sujeito em Análise do Discurso. In: MITTMANN, Solange; GRIGOLETTO, Evandra; CAZARIN, Ercília (Org.). Práticas discursivas e idenditárias: sujeito e língua. Porto Alegre: Nova Prova.

MATTA, Roberto da. 1987. Carnavais, malandros e heróis - para uma sociologia do dilema brasileiro. Rio de Janeiro: Rocco.

ORLANDI, Eni Pulcinelli. 1984. "Segmentar ou recortar?". Lingüística: questões e controvérsias. Série Estudos 10. Curso de Letras do Centro de Ciências Humanas e Letras das Faculdades Integradas de Uberaba. 
ORTIZ, Renato. 1980. Reflexões sobre o carnaval II. $C E R U, \mathrm{n}^{\circ} 11,1^{\mathrm{a}}$ série.

PÊCHEUX, Michel. 1990. Discurso: estrutura ou acontecimento. Campinas: Pontes.

SILVA, Augusto Neves. 2010. Reflexões sobre o carnaval e samba na historiografia brasileira. Revista Tempo Histórico. vol.2, $\mathrm{n}^{\circ} 2$. Disponível em: http://www.revista.ufpe.br/revistatempohistorico/index.php/revista/article/view/1614. Acesso em 11 março 2014.

SOIHET, Rachel. 1998. A subversão pelo riso. Estudos sobre o carnaval carioca da Belle Époque ao tempo de Vargas. Rio de Janeiro: Editora da Fundação Getúlio Vargas.

ZOPPI-FONTANA, Mónica. 1997. Cidadãos modernos. Campinas: Editora da Unicamp. 
Para citar essa obra:

GARCIA, D. A.. SOUSA, L. M. A.. "No carnaval a fantasia é minha. O corpo é meu": memória e rupturas feministas na folia In: $R U A$ [online]. no. 21. Volume 1, p. 87 - 107 ISSN 1413-2109. Junho/2015. Consultada no Portal Labeurb - Revista do Laboratório de Estudos Urbanos do Núcleo de Desenvolvimento da Criatividade.

http://www.labeurb.unicamp.br/rua/

Capa: : Movimento Mulheres em luta. Disponível em:

https://www.facebook.com/media/set/?set=a.217817528408105.1073741829.21722061 1801130\&type $=1$

Laboratório de Estudos Urbanos - LABEURB

Núcleo de Desenvolvimento da Criatividade - NUDECRI Universidade Estadual de Campinas - UNICAMP

http://www.labeurb.unicamp.br/

Endereço:

LABEURB - LABORATÓRIO DE ESTUDOS URBANOS UNICAMP/COCEN /

NUDECRI

CAIXA POSTAL 6166

Campinas/SP - Brasil

CEP 13083-892

Fone/ Fax: (19) 3521-7900

Contato: http://www.labeurb.unicamp.br/contato 